\title{
PENGABDIAN KEPADA MASYARAKAT MELALUI SOSIALISASI MENGENAI PEMBUKUAN SEDERHANA BAGI USAHA BATU BATA DI KELURAHAN TALANG JAMBE
}

\author{
Reny Aziatul Pebriani1) \\ 1)Program Studi Akuntansi, Universitas Indo Global Mandiri \\ Jalan Jenderal Sudirman No. 629 Palembang Kode pos 30129 \\ Email : renyaziatul@uigm.ac.id ${ }^{1)}$
}

\begin{abstract}
ABSTRAK
Dalam rangka pembangunan pedesaan perlu adanya pendampingan yang dinamakan fasilitator, karena ketidaktahuan tentang bagaimana merencanakan serta bagaimana menyiasati sehingga pembangunan pedesaan terlaksana. Tim pengabdian dosen Fakultas Ekonomi melakukan pengabdian sosialisasi mengenai pembukuan sederhana bagi usaha batu bata di Kelurahan Talang Jambe Kota Palembang. Tujuan diadakannya pengabdian ini adalah agar para pelaku usaha batu bata dapat memahami dan kedepannya dapat membuat pembukuan sederhana dan rencana kerja serta sasaran yang akan dicapai. Untuk mencapai tujuan tersebut, telah dilakukan sosialisasi kegiatan pada minggu kedua di kegiatan KKN BBM yaitu diselenggarakannnya sosialisasi mengenai pembukuan sederhana bagi usaha batu bata. Pelaksanaan sosialisasi dimulai dari penyajian materi secara lugas dilanjutkan dengan sistem interaksi tanya jawab antara peserta dan narasumber. Kegiatan sosialisasi ini diharapkan dapat bermanfaat bagi pelaku usaha mandiri yaitu usaha batu bata yang telah merintis usahanya maupun yang baru memulai usahanya kemudian melalui sosialisasi ini diharapkan dapat memberikan tambahan pengetahuan bagi para usaha mandiri di Desa Talang Jambe dalam mengatasi permasalahan yang sangat kompleks yang mereka hadapi dalam usahanya khususnya pada pembukuan sederhana.
\end{abstract}

Kata kunci : Sosialisasi, Pembukuan sederhana, usaha mandiri

\section{PENDAHULUAN}

Universitas Indo Global Mandiri (IGM) merupakan salah satu perguruan tinggi swasta yang ada di Palembang. Perguruan tinggi tersebut menjadi bagian integral dari masyarakat yang turut bertanggung jawab terhadap berbagai persoalan yang ada di masyarakat. Bentuk tanggung jawab Universitas Indo Global Mandiri yaitu academic social responsibility perguruan tinggi (PT), memiliki tanggung jawab moral untuk mengatasi berbagai persoalan ekonomi sosial dengan segala metamorfosenya dan memajukan pembangunan bangsa. Bentuk tanggung jawab tersebut berupa pelaksanaan Tridharma perguruan tinggi yaitu yang meliputi kegiatan pendidikan dan pengajaran, penelitian serta pengabdian kepada masyarakat. Fakultas Ekonomi sebagai bagian dari UIGM tahun 2019 ini memiliki program pengabdian kepada masyarakat yang diselenggarakan oleh dosen sesuai dengan Visi dan Misi Universitas melalui kegiatan Kuliah Kerja Nyata (KKN).

Salah satu kegiatan yang dilakukan pada KKN ini adalah mensosialisasikan mengenai pentingnya memiliki pengetahuan mengenai pembukuan sederhana bagi para usaha kecil yang sebagian besar merupakan masyarakat di Desa Talang Jambe. Meskipun beberapa wirausahawan tersebut sudah menempuh pendidikan formal, namun tidak semua memiliki latar belakang pendidikan akuntansi maupun manajemen. Sehingga, dalam pengelolaan bisnis mereka sering kali mengalami hambatan. Hal ini terlihat dari pengelolaan keuangan dan akuntansi yang dilakukan masih terbatas dengan skala kecil. Selain itu, perkembangan teknologi informasi yang semakin maju harus dapat dikuasai oleh para usaha kecil agar dapat mengembangkan bisnisnya. Pengelolaan keuangan yang berbasis teknologi juga menjadi penunjang untuk kesuksesan bisnis agar lebih akurat dalam mengatur keuangan sehingga dapat menarik minat investor. Sebagian besar mata pencarian masyarakat kelurahan Talang Jambe yaitu sebagai pengrajin batu bata press, yang dimana masyarakat sekitar memiliki tempat pengelolahan sendiri di dekat kediaman masyarakat setempat. 
Menurut undang-undang No 28 tahun 2007, pembukuan sederhana dapat diartikan sebagai suatu proses pencatatan yang dilakukan secara teratur untuk mengumpulkan data dan informasi keuangan. Pencatatan keuangan ini meliputi harta, kewajiban, modal, penghasilan, dan biaya serta jumlah harga perolehan dan penyerahan barang atau jasa. Kemudian bisa ditutup dengan menyusun laporan keuangan berupa neraca dan laporan laba rugi pada periode tersebut.

Sebagai bagian integral dari sistem pendidikan tinggi maka melalui KKN-BBM diharapkan sosialisasi mengenai pembukuan sederhana bagi usaha batu bata di kelurahan Talang Jambe Kecamatan Sukarame kota Palembang dapat memberikan tambahan pengetahuan bagi para usaha mandiri di Desa Talang Jambe dalam mengatasi permasalahan yang sangat kompleks yang mereka hadapi dalam usahanya khususnya pada pembukuan sederhana. Bersamaan dengan hal itu, mahasiswa juga sekaligus melakukan kegiatan belajar bersama masyarakat untuk menanggulangi berbagai permasalahan yang ada dalam masyarakat secara pragmatis dan interdisipliner.

\subsection{Tujuan PkM}

1. Untuk meningkatkan pengetahuan bagi para pelaku usaha mandiri batu bata mengenai pentingnya pembukuan sederhana bagi usaha mereka.

2. Untuk meningkatkan kemampuan mereka dalam membuat pembukuan sederhana.

\subsection{Manfaat PkM}

1. Bagi peserta dengan kegiatan sosialisasi ini diharapkan dapat meningkatkan pengetahuan tentang pentingnya pembukuan sederhana bagi usaha mereka.

2. Bagi peserta dengan kegiatan pelatihan ini diharapkan dapat meningkatkan kemampuannya dalam menyusun pembukuan sederhana.

\section{METODE PELAKSANAAN PENGABDIAN}

\subsection{Tahapan Pelaksanaan Kegiatan PKM}

Pengabdian pada masyarakat berupa sosialisasi mengenai pembukuan sederhana bagi usaha batu bata di kelurahan Talang Jambe kota Palembang diawali dengan persiapan yang terencana karena sosialisasi ini mengikut sertakan masyarakat khususnya pelaku usaha mandiri yaitu usaha batu bata sebagai partisipatif. Artinya masyarakat diharapkan berpartisipasi sedangkan dosen dan mahasiswa peserta sosialisasi bertindak sebagai fasilitator dan penggerak dalam sosialisasi mengenai pembukuan sederhana bagi usaha batu bata. Kegiatan pengabdian kepada masyarakat di Desa Talang Jambe Kecamatan Sukarame Kota Palembang dilaksanakan pada bulan Januari sampai Februari bertempat di salah satu rumah RT di RW 02 Kelurahan Talang Jambe. Kegiatan yang dilaksanakan meliputi Sosialisasi mengenai pembukuan sederhana bagi usaha batu bata di kelurahan Talang Jambe.

Kegiatan sosialisasi mengenai pembukuan sederhana bagi usaha batu bata di kelurahan Talang Jambe dilakukan melalui tahapan sebagai berikut :

1. Persiapan kegiatan meliputi :

a. Kegiatan survei tempat pengabdian kepada masyarakat yaitu di Desa Talang Jambe Kecamatan Sukarame Kota Palembang.

b. Permohonan ijin kegiatan pengabdian kepada masyarakat kepada Lurah Talang Jambe Kecamatan Sukarame Kota Palembang.

c. Pengurusan administrasi (surat-menyurat).

d. Persiapan alat dan bahan serta akomodasi.

e. Persiapan tempat untuk sosialisasi yaitu menggunakan salah satu rumah ketua RT Desa Talang Jambe.

2. Kegiatan sosialisasi mengenai pembukuan sederhana bagi usaha batu bata di kelurahan Talang Jambe meliputi :

a. Pembukaan dan perkenalan dengan pelaku usaha mandiri yaitu usaha batu bata di Desa Talang Jambe Kecamatan Sukarame Kota Palembang yang menjadi sasaran kegiatan.

b. Sosialisasi mengenai pentingnya membuat pembukuan sederhana bagi para usaha mandiri yaitu usaha batu bata. 
c. Sesi diskusi/tanya jawab dengan peserta pelaku usaha mandiri yaitu pengusaha batu bata mengenai pembukuan sederhana.

3. Penutupan

a. Pemberian door prize bagi pelaku usaha batu bata yang mampu menjawab pertanyaan.

b. Foto bersama dengan peserta usaha batu bata.

c. Berpamitan dengan pengurus dan ketua RT Talang Jambe Kecamatan Sukarame Kota Palembang.

d. Pembuatan laporan pengabdian pada masyarakat.

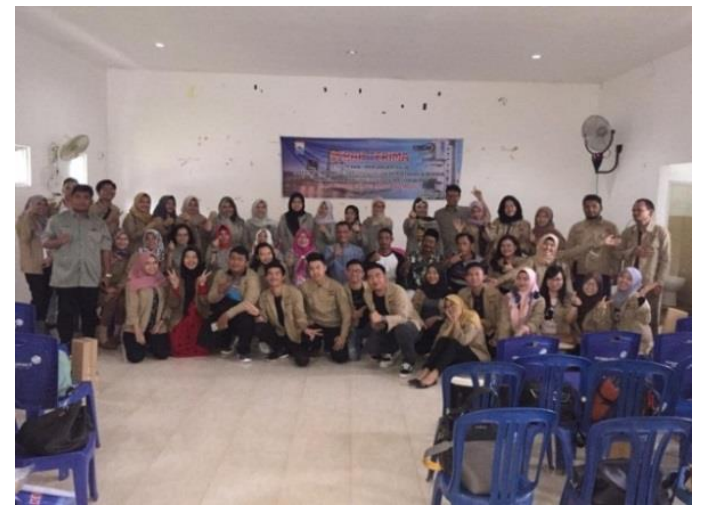

Gambar 1. Persiapan sosialisasi

\subsection{Analisa dan Solusi Permasalahan Mitra}

Analisa dan solusi permasalahan Mitra melalui pendekatan sebelumnya yakni melalui survei dan wawancara dengan pihak Pelaku Usaha Mandiri yaitu usaha batu bata. Dalam analisa tersebut didapat beberapa tahapan dalam pembukuan sederhana bagi usaha batu bata, maka didapat analisa permasalahan yaitu para pelaku usaha mandiri yaitu usaha batu bata tidak melakukan pembukuan pada produksi, pengeluaran dan pemasukan dari usaha mereka sehingga melalui sosialisasi ini para pelaku usaha batu bata dapat mulai melaakukan pembukuan sederhana dapat sebagai suatu proses pencatatan yang dilakukan secara teratur untuk mengumpulkan data dan informasi keuangan usaha mereka.

\subsection{Kesepakatan dengan Pihak Pelaku Usaha}

Kesepakatan dengan pihak pelaku usaha mandiri yaitu usaha batu bata mengenai waktu dan tempat pelaksanaan kegiatan KKN tersebut. Pihak Kampus UIGM menginformasikan kepada pelaku usaha mandiri batu Bata di Talang Jambe untuk mengikuti sosialisasi beberapa tahapan dalam pembukuan sederhana. Sosisalisasi tersebut dapat diikuti seluruh pelaku usaha mandiri batu bata di Desa Talang Jambe.

\subsection{Persiapan Pelaksanaan}

Persiapan perlaksanaan sosisalisasi ini dilakukan secara terurut dimana bukan hanya mahasiswa saja selaku tim yang akan mensosialisasikan pembukuan sederhana tetapi masyarakat pelaku usaha mandiri yaitu batu bata yang ada ditalang jambe. Sehubungan dengan persiapan pelaksanaan tersebut diharapkan hasil dari sosialisasi ini para pelaku usaha mandiri batu bata dapat menerapkan pembukuan pada usaha mereka yang tujuan akhirnya agar mereka mengetahui aliran dana dan keuntungan yang mereka dapat.

\subsection{Pelaksanaan Pengabdian}

Kegiatan sosialisasi ini dilakasanakan pada kegiatan KKN BBM yang dilaksanakan dalam waktu minggu kedua s.d minggu ke tiga pada bulan Januari 2019. 
Tabel 1. Jadwal Pelaksanaan kegiatan sosialisasi mengenai pembukuan sederhana bagi usaha batu bata di kelurahan Talang Jambe.

\begin{tabular}{|c|c|l|}
\hline Tanggal & Waktu & \multicolumn{1}{|c|}{ Materi } \\
\hline 12 Januari 2019 & $08.00-09.30$ & $\begin{array}{l}\text { Sosialisasi mengenai pembukuan } \\
\text { sederhana bagi usaha batu bata. }\end{array}$ \\
\cline { 2 - 3 } & $10.00-12.00$ & $\begin{array}{l}\text { Tanya Jawab dan diskusi mengenai } \\
\text { materi yang disosialisasikan. }\end{array}$ \\
\cline { 2 - 3 } & $12.00-13.00$ & Ishoma \\
\cline { 2 - 3 } & $13.00-16.00$ & Sosialisasi Lanjutan \\
\cline { 2 - 3 } & $16.00-17.00$ & Penutup \\
\hline
\end{tabular}
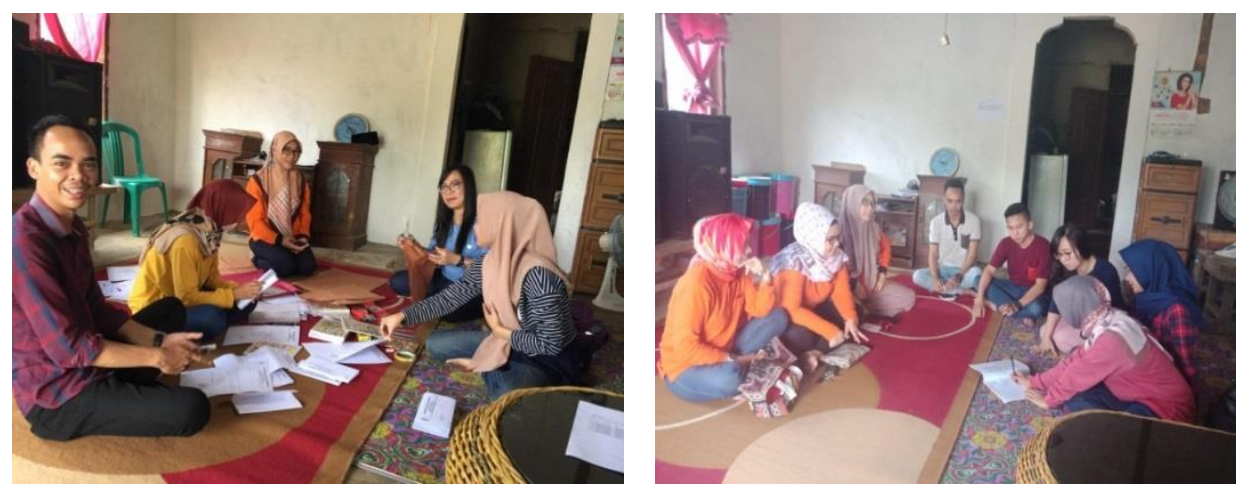

Gambar 2. Persiapan sosialisasi di rumah ketua RT

\section{HASIL DAN PEMBAHASAN}

Pada dasarnya masyarakat pedesaaan khususnya desa Talang Jambe mendukung sepenuhnya kegiatan mahasiswa dilapangan. Dari kegiatan pengabdian ini dampak positif yang dirasakan oleh masyarakat yang punya usaha adalah sebagai berikut :

1. Pengembangan perekonomian desa

Dengan adanya kegiatan pengabdian ini para penduduk desa yang memiliki usaha mandiri dikenalkan pada pencatatan dan pembukuan sederhana, diharapkan mereka dapat menerapkan apa yang telah dipelajari ke dalam praktek pengelolaan usaha mandiri batu bata.

2. Peningkatan kesejahteraan keluarga

Salah satu materi pelatihan yang dibawakan adalah mengenai pencatatan pembukuan sederhana dan pengenalan akan investasi. Dengan adanya pengetahuan ini diharapkan keluarga dapat melakukan perencanaan keuangan yang lebih baik sehingga pada akhirnya dapat meningkatkan kesejahteraan keluarga. Hal ini tentunya dapat pula berdampak positif pada kesejahteraan masyarakat desa pada umumnya.

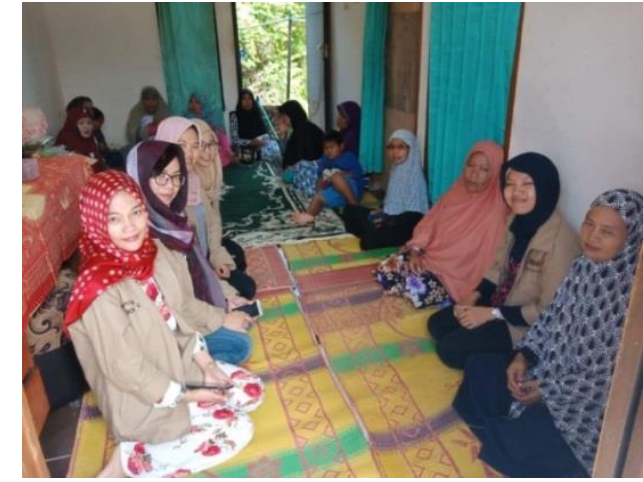

Gambar 3. Para pelaku usaha Batu Bata

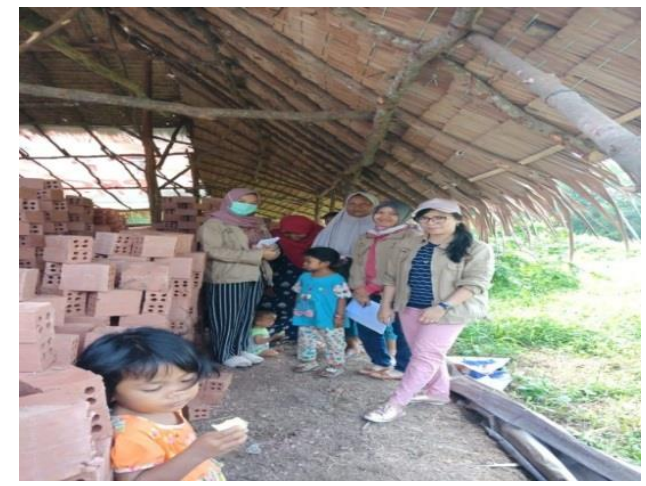

Gambar 4. Tempat usaha batu bata warga 


\section{KESIMPULAN}

Kegiatan sosialisasi mengenai pembukuan sederhana bagi usaha mandiri batu bata untuk meningkatkan kinerja keuangan perusahaan berjalan dengan lancar. Semua peserta antusias mengikuti acara hingga selesai dan merasakan manfaat pelatihan bagi kemajuan usaha mereka dan menambah pemahaman kepada masyarakat dalam merencanakan rencana kerja yang efektif dan efisien terhadap usaha mereka.

\section{UCAPAN TERIMA KASIH}

Ucapan terimakasih diberikan kepada Universitas Indo Global Mandiri selaku pelindung dalam kegiatan ini. Mahasiswa selaku fasilisator dan dosen selaku pembimbing dan masyarakat Desa Talang Jambe selaku peserta kegiatan sosialisasi ini.

\section{DAFTAR PUSTAKA}

Buku Pedoman KKN BBM Fakultas Ekonomi Universitas Indo Global Mandiri Endra Murti Sagoro. 2012. Akuntansi Tanpa Stres. Yogyakarta: AB Publiser.

Pemerintah Republik Indonesia. 2007. Undang-Undang Nomor 28 Tahun 2007 tentang Ketentuan Umum dan Tata Cara Perpajakan.

Sony Warsono. 2009. Akuntansi ternyata Logis dan Mudah. Yogyakarta: Asgard Chapter 